\title{
Heat and Ozone Resistance of Bacillus Spores Isolated from Laboratory Animals
}

\author{
Tian Mei PAN, Ying Xia LIU, Kouji SHIMODA, Kazuyoshi MAEJIMA, Takatoshi \\ KUHARA*, Toru URANO**, Tomoaki ISHIHARA***, \\ and Noriyuki KASAI****
}

Keio University School of Medicine, 35 Shinanomachi, Shinjuku-ku, Tokyo 160, *Teikyo

University School of Medicine, Itabashi-ku, Tokyo 173, ** Kumamoto University School of Medicine, Kumamoto 860, ${ }^{* * *}$ Hokkaido University, Institute

of Immunological Science, Sapporo 060, and ${ }^{* * * *}$ Hokkaido

University School of Medicine, Sapporo 060, Japan

(Received 15 December 1989/Accepted 2 March 1990)

\begin{abstract}
Heat resistance of free-spores of 78 Bacillus strains isolated from laboratory animals was examined. Spores of 41 out of 78 strains survived for 320 minutes at $70^{\circ} \mathrm{C}$, 27 for $160 \mathrm{~min}$. at $100^{\circ} \mathrm{C}$, only one for $20 \mathrm{~min}$. at $110^{\circ} \mathrm{C}$ by autoclaving, and none for $5 \mathrm{~min}$. at $120^{\circ} \mathrm{C}$. D-values at $100^{\circ} \mathrm{C}$ of 9 strains determined were between 5.03 and $30.06 \mathrm{~min}$. Spores of 9 strains from stock cultures were exposed to ozone gas at various conditions. Ozone resistance of spores was closely dependent upon relative humidity. D-values of the spores tested by treatment with $200 \mathrm{ppm}$ ozone at $60 \% \mathrm{RH}$ were over $200 \mathrm{~min}$., especially over $1,000 \mathrm{~min}$. in 4 strains, indicating that exposure to ozone at a moderate humidity for 6 hours could not sterilize Bacillus spores. At $90 \% \mathrm{RH}$, however, treatment with $200 \mathrm{ppm}$ ozone for $6 \mathrm{hr}$. might be effective for a routine sterilization in laboratory animal facilities.
\end{abstract}

\section{実験動物由来 Bacillus 芽胞の熱およびオゾン抵抗性 \\ 潘 甜 美・柳 英 侠 -下田耕治 - 前島一淑・久原孝俊* \\ 浦野徹**・石原智明***・笠井憲雪**** \\ 慶応義塾大学医学部実験動物センター \\ *帝京大学医学部動物実験施設 \\ **能本大学医学部動物実験施設 \\ ***北海道大学免疫科学研究所免疫動物実験施設 \\ ****北海道大学医学部動物実験施設}

一般に, 実験動物施設の堿菌, 消毒作業には, ヒトや 家畜の衛生管理の場で用いられている殺菌あるいは不活 化 (以下殺菌) 技術がほとんどそのまま用いられてい る。この殺菌技術は微生物学の原理に基づいて確立され たものであるから，基本的には，対象が実験動物であっ てもヒトや家畜であっても適用上の差異はない筈である が, 実験動物施設とい5特殊な場に適合する隇菌, 消毒
操作を確立するため, 文部省科学研究費による総合研究 が昭和 60 年から 3 年間実施された。具体的には, 実験動 物由来の各種病原ウイルス, マイコプラズマ, 細菌, 真 菌, 寄生虫を対象としてさまざまな殺菌処理の効果が詳 細に検討され，実用性や消毒薬の毒性を考虑したらえ 1 つの標準的操作が提案された [5]。

この研究の一環として, 実験動物から収集した好気性 
芽胞形成桿菌（以下 Bacillus）芽胞の熱抵抗性が検索 され，その 1 部は柳らによって第34回日本実験動物学会 総会（岡山, 昭和62年）に扣いて口頭発表されたが，そ の後, 実験動物施設の新しい减菌, 消毒手段としてオデ ン燻蒸の有用性が注目され始めたので, 上記 Bacillus 芽胞のオゾンガス抵抗性に関する検索に着手した。著者 らの最終目的は, 実験動物衛生管理のための 1 手段とし てオン゙ン燻蒸法を加えることで, 本論文は, そのための 基礎ならびに応用研究の最初の報告である。

\section{実験方法}

[供試菌株]度応義塾大学医学部実験動物センター, 熊 本大学医学部動物実験施設, 北海道大学医学部動物実験 施設打よび免疫科学研究所免疫動物実験施設で飼育中の マウス, ウサギ, イヌの蕒便から分離した Bacillus 株 を用いた。まず，マウス，ウサギあるいはイヌの新鮮䔬 便を採取し, 100倍量 (W/V) の隇菌リン酸塩緩衝生理 食塩水（pH 7.0: 以下 PBS）を加えて磨碀した。この 翼便懸濁液の $2 \mathrm{ml}$ ずつを径 $1 \mathrm{~cm}$ の小試験管に入れ，恒
温水槽にて70 C 20 分処理後, その 1 白金耳をハートイン フュージョン（以下 HI）カンテン平板に塗抹し， $37^{\circ} \mathrm{C}$ 2 日間培養した。発育集落を採取し, HI カンテン平板 上で $37^{\circ} \mathrm{C} 1$ 日培養を繰返して純化し, HI カンテン斜面 に登抹して室温保存すると同時に, 菌体の幅, 芽胞の形 状, 空胞の有無を含む形態学ならびに各種性状（カタラ 一セ，VP, 尿素利用, タンパク分解, 糖分解, 食塩抵 抗，硝酸塩還元等）について検査した $[6]$ 。最終的な供 試菌株は，マウス由来 24 （慶大 15 , 熊大 9 ）株, ウサギ 由来 36 （慶大 20 , 熊大 8 , 北大 8 ）株, イヌ由来 18 （慶 大 7 , 熊大 6 , 北大 5 ）株の計78株で, この5ちの37株 が Bacillus licheniformis, 25株が B. subtilis, 4 株 が B. cereus, 3 株が B. coagulans, 残る 9 株が同定 不能であった。

[熱抵抗性試験]保存菌株を HI カンテン斜面に移し, $37^{\circ} \mathrm{C} 1$ 晚培養によって活性化させた後，それぞれを数本 の HI カンテン斜面上に塗抹して37 C 3 日間培養した。 その菌苔をかき取り，PBSに愁濁してょく醔拌し，隇 菌滤紙（東洋C 5 : 東洋製作所）で濾過し， $4^{\circ}$ C 保存 した。芽胞夜は，必要に応じて70²0分間加熱して栄着

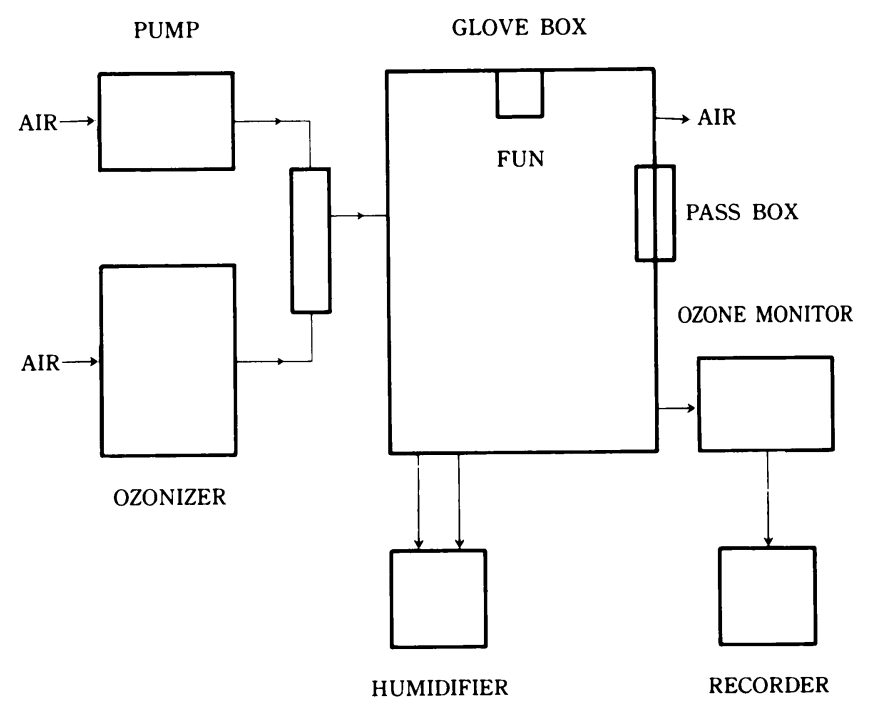

Fig. 1. Diagram of ozonizing apparatus

Table 1. Heat resistance of bacillus spores (Qualitative test)

\begin{tabular}{cccccccccccc}
\hline Unheated & \multicolumn{3}{c}{$70^{\circ} \mathrm{C}$} & \multicolumn{3}{c}{$100^{\circ} \mathrm{C}$} & \multicolumn{2}{c}{$110^{\circ} \mathrm{C}$} & \multicolumn{2}{c}{$120^{\circ} \mathrm{C}$} \\
\cline { 2 - 12 } Control & 80 & 160 & $320 \mathrm{~min}$. & 40 & 80 & $160 \mathrm{~min}$. & 5 & 10 & $20 \mathrm{~min}$. & 5 & $10 \mathrm{~min}$. \\
\hline $78^{*}$ & 76 & 72 & 41 & 55 & 49 & 27 & 5 & 4 & 1 & 0 & 0 \\
\hline
\end{tabular}

* : No. of strains showing positive culture after heat treatment 
Table 2. D-values of bacillus spores at $70^{\circ} \mathrm{C}$ and $100{ }^{\circ} \mathrm{C}$ treatment

\begin{tabular}{crrll}
\hline $\begin{array}{c}\text { No. of } \\
\text { Strains }\end{array}$ & $\begin{array}{c}\text { Heated } \\
\text { at (C) }\end{array}$ & D-value & $\begin{array}{l}\text { Origin } \\
\text { of Strains }\end{array}$ & Species \\
\hline 11 & 70 & $107.16^{*}$ & Rabbit & B. subtilis \\
& 100 & 8.21 & Keio U. & \\
\hline \multirow{2}{*}{16} & 70 & 21.55 & Rabbit & B. subtilis \\
& 100 & 6.43 & Keio U. & \\
\hline 22 & 70 & $\infty^{* *}$ & Rabbit & B. licheniformis \\
& 100 & 14.67 & Keio U. & \\
\hline 43 & 70 & 86.73 & Mouse & B. licheniformis \\
& 100 & 30.06 & Kumamoto U. & \\
\hline 52 & 70 & 82.44 & Rabbit & B. subtilis \\
& 100 & 13.47 & Kumamoto U. & \\
\hline 58 & 70 & 187.37 & Rabbit & B. licheniformis \\
& 100 & 17.22 & Kumamoto U. & \\
\hline 60 & 70 & 124.11 & Dog & B. licheniformis \\
& 100 & 5.03 & Kumamoto U. & \\
\hline 67 & 70 & 118.65 & Rabbit & B. licheniformis \\
& 100 & 20.85 & Hokkaido U. & \\
\hline 77 & 70 & 67.08 & Dog & B. licheniformis \\
& 100 & 11.65 & Hokkaido U. & \\
\hline
\end{tabular}

* : $10 \%$ survival time in minute

Table 3. D-values of spores exposed to $200 \mathrm{ppm}$ of ozone gas at various relative humidity

\begin{tabular}{cccc}
\hline \multirow{2}{*}{$\begin{array}{l}\text { No. of } \\
\text { strains }\end{array}$} & \multicolumn{3}{c}{ Relative humidity } \\
\cline { 2 - 4 } & $60 \%$ & $75 \%$ & $90 \%$ \\
\hline 11 & $214.2^{*}$ & 285.6 & 52.8 \\
16 & $\infty{ }^{* *}$ & $\infty$ & 42.0 \\
22 & $\infty$ & $\infty$ & 55.2 \\
43 & 352.8 & 100.2 & 64.8 \\
52 & $\infty$ & 240.0 & 62.4 \\
58 & 315.6 & 120.0 & 84.6 \\
60 & $\infty$ & 461.4 & 61.8 \\
67 & 750.0 & 285.6 & 52.8 \\
77 & 375.0 & 85.2 & 33.6 \\
\hline$*: 10 \%$ survival time in minute & $* *:>1,000$
\end{tabular}

型菌を殺し， HI 寒天平板を用いて「生きている」芽胞 数を数え, $\mathrm{ml}$ 当たりの芽胞数を $10^{5} な い し 10^{6}$ 個に調整 した。芽胞液は径 $1 \mathrm{~cm}$ の小試験管に $1 \mathrm{ml}$ ずつ分注し， 恒温水槽, 沸騰水あるいはスピードオートクレーブ（ト : - : S 90N）によって加熱処理し, 所定の処理後は試 験管を流水中に漬けて急冷した。恒温水槽および沸騰水
Table 4. D-values of spores exposed to different concentration of ozone gas at $90 \%$ relative humidity

\begin{tabular}{cccc}
\hline \multirow{2}{*}{$\begin{array}{l}\text { No. of } \\
\text { strains }\end{array}$} & \multicolumn{3}{c}{ Ozone gas concentration } \\
\cline { 2 - 4 } & $50 \mathrm{ppm}$ & $100 \mathrm{ppm}$ & $200 \mathrm{ppm}$ \\
\hline 11 & $124.8^{*}$ & 44.4 & 52.8 \\
16 & 273.0 & 48.0 & 48.6 \\
22 & $\infty^{* *}$ & 157.8 & 54.6 \\
43 & 88.2 & 58.2 & 64.8 \\
52 & $\infty$ & 89.4 & 89.4 \\
58 & 111.0 & 127.8 & 84.6 \\
60 & $\infty$ & 124.8 & 71.4 \\
67 & 666.6 & 93.6 & 51.0 \\
77 & 71.4 & 45.0 & 49.8 \\
\hline$* 10 \%$ survival time in minute & $* *:>1,000$
\end{tabular}

中においては, 試験管内の試料温度は 30 秒以内に所定温 度に達したが, オートクレーブの場合は, 温度計が室温 から 100 Cに達するに $15.10 \pm 0.42$ 分, $110^{\circ} \mathrm{CKは} 18.60 \pm$ 0.82分， $120^{\circ} \mathrm{C}$ には23. $70 \pm 0.67$ 分を要した（平均士標準 偏差)。また，オートクレーブ処理後, 温度計が $120^{\circ} \mathrm{Cな}$ らびに110から99゚に下がるに要した時間は，15.10士 
0.41 分ならびに9.2 0.35 分であった。芽胞の生死に関 する定性的な判定は，加熱処理した芽胞液に HI ブイ ヨン $5 \mathrm{ml}$ を加え, $37^{\circ} \mathrm{C} 7$ 日間培養後の発育の有無によ った。生残した芽胞数は, 常法どおり, 各希釈段階 2 枚 の HIカンテン平板を用いて算定した。

[オゾンガス抵抗性試験のための芽胞浮遊液】上記78株 の中から選んだ 9 株を、オン゙ンガス抵抗性試験に用い た。これらの菌株の由来と菌種は Table 2 に記してあ る。まず，保存菌株の微量を $3 \mathrm{ml}$ の HI ブロスを用いて 2 回, $37^{\circ} \mathrm{C} 24$ 時間静置培養を繰返して活性を高めた後, その $1 \mathrm{ml}$ を $200 \mathrm{ml}$ の HI ブロス(角瓶) 3 本に移して $37^{\circ} \mathrm{C}$ 72時間震湯培養した。つづいて, 隇菌 PBS（pH 7.0） を用いて $4{ }^{\circ} \mathrm{C}, 3,000 \mathrm{rpm}, 30$ 分間の遠心洗浄を 3 回行 い, 最終的に $2 \mathrm{ml}$ の菌浮遊液に濃縮した。これに $70^{\circ} \mathrm{C}$ 20分間の加熱処理を加えて栄養型菌を殺して芽胞型菌の みを残し，強く震梄したのち隇菌滤紙（東洋C 5 : 東洋 製作所）で滤過し，大きな芽胞塊をとり除いた。芽胞浮 遊液の生菌数は，上記と同様に $\mathrm{HI}$ カンテン平板を用い て算定し, 诚菌 PBSにて0.02ml 当たり約 $10^{\circ}$ 個となる よらに希釈した。続いて，この希釈芽胞液を乾熱減菌し た抗生物質感受性試験ディスク用滤紙(径 $8 \mathrm{~mm}$ : 東洋製 作所）に0.02mlずつ滴下して浸込ませ,隇菌したフィ ルタキャップ付きマウスケージ内で自然幹燥させた（以

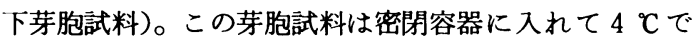
保存した（芽胞生菌数がこの条件で安定であることは確 認済み)。

〔オゾンガス暴露〕芽胞試料は, オゾン発生装置（新菱 冷熱㑣 ELIOS-AR）のグローブボックス内で湿度 60，75または $90 \%$ 、オゾン濃度 50,100 または $200 \mathrm{ppm}$ の条件で $1 ， 2 ， 4$ および 6 時間暴露した。温度は，す べて21〜22孚の範囲にあった。オゾン暴露直前 ( 0 時間) およびオゾン暴露後, ただちにそれぞれの芽胞試料（滤 紙）を $10 \mathrm{ml}$ の堿菌 PBS を入れた中試験管に入れ，ガラ ス棒を使って十分に磨䂽した。この原液ならびにその10 倍段階希䣋液の各 $0.1 \mathrm{ml}$ を 2 枚の $\mathrm{HI}$ カンテン平板に滴 下し、コンラージ棒で広げて 37 C培着し，48時間後の集 落数を数えた。なお，Fig. 1 はオゾン発生装置の模式図 で，オゾナイザによって発生させたオン゙ンガスは，コン プレッサからの空気と混合されて所定濃度に調整され， グローブボックス内に送られる。グローブボックスに は, オゾン湿度を調節, 記録するためのオゾンモ二タ, オゾンレコーダならびに湿度を調整するための加湿器が 連結されている。また，グローブボックス内の天井に は, オゾン浱度を㚬一にするための筧汼用ファンが取付 けられている。芽胞試料の出入れは，パスボックスを経
由する。

\section{成}

1. 熱抵抗性試験：Table 1は, 78菌株の芽胞 $\left(10^{5} \sim\right.$ $10^{6}$ 個) について, $70^{\circ} \mathrm{C}$ (恒温水槽), $100^{\circ} \mathrm{C}$ (沸騰水), $110^{\circ} \mathrm{C}$ および $120^{\circ} \mathrm{C}$ (オートクレーブ) 処理で生残した菌 株数を示している。78菌株中 76 菌株が70 C80分の加熱に 耐之， $70^{\circ}$ C320分でも41菌株が生残した。 $100^{\circ} \mathrm{C}$ の処理に 対して49菌株が80分，27菌株が160分の加熱に抵抗した。 また， $110^{\circ} \mathrm{C} 5$ 分（オートクレーブ）処理に対して少な くとも5 菌株が，20分処理でも1菌株が抵抗したが， $120^{\circ} \mathrm{C}$ 処理に耐之た芽胞はなかった。熱抵抗性と菌株の 由来の間に関連性は認められなかった。

つぎに78菌株の中から無作為的に 9 菌株を選び出し, $10^{5}$ ないし10 個を浮遊させた $1 \mathrm{ml}$ の PBS に $70^{\circ}$ あるい は $100^{\circ} \mathrm{C} て ゙ 20 ， 40 ， 60 ， 80$ 分の加熱処理を施した。各処 理条件において生残った芽胞数の減少直線 (一次回㷌曲 線）から算出された D 值（10\%生残時間）を Table 2 に示した。例えば菌株22，43，58，67の芽胞は70処理 にも 100 C処理にも強く抵抗した。 $70^{\circ}$ C処理においてもっ とも耐熱性をもつ芽胞は菌株22で，D值は計算できない ほど大きかった（100`CのD值は14.67分）。表では1, 000 分以上のD值をのと表示した。菌株 22 のつぎに $70^{\circ} \mathrm{C}$ 処理 に耐えた芽胞は菌株58でD値は 187.37 分であった（100 Cのそれは17.22分)。一方, 100 C処理に対してもっと も抵抗した芽胞は菌株43で，D值は30.06分であった(70 ○のそれは86.73分)。このよ5に, $70^{\circ} \mathrm{C}$ 処理と $100^{\circ} \mathrm{C}$ 処 理におけけ D值の間の強い関連を示す結果は得られなか った $(\mathrm{r}=0.2184)$ 。

2.オゾン抵抗性試験：保存78菌株より9 菌株を選 びそそれぞれ106個の芽胞を浸込ませて自然乾燥させた 濾紙 (芽胞試料)を200ppm (198 220ppm) のオン゙ン に60，120および240分暴露した。湿度は60，75，90\%の 3 段階（温度はいずれす21 220 C) に設定した。生残し た芽胞数の減少曲線（一次回帰曲線）より算出された D 值（10\%生残時間）をTable 3 に示した。検出限界は 試料あたり100個である。

その結果, 湿度60\%の条件においては, 200ppm オン゙ ンに対する抵抗性がもっとも低い芽胞（菌株11）でも， $90 \%$ 死隇させるのに200分以上を必要とした。菌株16, 22，52，60の D值は1，000分を越えた ( $\infty$ と表示)。湿度 75\%の条件に沶いても，菌株77の芽胞を除いては，90\% を死滅させるのに100分以上の暴露を必要とした。しか し，湿度を $90 \%$ に於ると，すべての芽胞は85分以内に その $90 \%$ が死隇した。なお， $100^{\circ} \mathrm{C}$ 加熱処理によるD値 
と湿度 $90 \%, 200 \mathrm{ppm}$ オゾン処理による D值の相関係数 は $\mathrm{r}=0.3640 て ゙ ，$ 相関は有意でなかった。

同じ 9 菌株を用い, 湿度 $90 \%(89 \sim 92 \%) ， 50,100 お よ$ び200 ppmの条件でのD值を測定した。その結果は Table 4 に示したように, 菌株43，77を除く芽胞は，50 ppm のオン゙ン暴露の場合, $90 \%$ 死隇させるために 100 分以上の処置を必要とした。100ppm に护けるD值も， 3 菌株が100分以上を示した。200ppm のD值は，湿度 条件を変えた前の実験（Table 3）のそれとよく一致し ていた。

Table 4 に示した測定値から計算された湿度 $90 \%$ ，才 ゾン濃度 $200 \mathrm{ppm}$ 処置における一次回㷌式は, 以下のと おりである。なお， $\mathrm{y} は$ は, オゾン暴露 $x$ 時間後の生残芽 胞数 (対数值) である。

菌侏11: $\mathrm{y}=4.91-1.14 x$

菌株 $22: \mathrm{y}=5.55-1.10 x$

菌株52: $\mathrm{y}=5.09-0.67 x$

菌株60: $\mathrm{y}=5.27-0.84 x$

菌株16: $\mathrm{y}=5.79-1.24 x$

菌株 $43: \mathrm{y}=4.31-0.93 x$

菌株58: $\mathrm{y}=4.93-0.71 x$

菌株67: $\mathrm{y}=5.51-1.18 x$

菌株77: $\mathrm{y}=5.29-1.21 x$

\section{考㲾}

Bacillus 芽胞の耐熱性は，芽胞を形成しない通常の 病原細菌やウイルス等のそれらよりはるかに大きく，こ れらの芽胞を確実に殺㙎できる加熱処理を行えば，実験 動物の病原体はすべて殺菌できると考えられる。ところ で，実験動物施設に常在している細菌芽胞の熱抵抗性を 測定した実験資料は，実験動物に対する病原体である Tyzzer 菌についての報告 $[1,2]$ を除いて見当らな い。今回の検討は，まず，わが国の 3 大学 4 実験動物施 設より Bacillus 株を収集するところから始めた。好気 性菌のみを対象とし, 嫌気性菌を対象としなかった理由 は，扱いが簡単であること，嫌気性菌が特別に高い抵抗 性をもっているとは考えられないことの 2 点による。

収集した78菌株中 41 菌株が $70^{\circ} \mathrm{C} 320$ 分, 27菌株が $100^{\circ} \mathrm{C}$ 160分，5菌株が110 5 分にそれぞれ抵抗したが，1200 処理に耐えた芽胞はなかった。 $70^{\circ}$ CにおけるD值は一般 に極めて大きく，殺菌手段を考える際の実際的な意味は ない。100年処理におけるD值は，5.03（菌株60）から 30.06分（菌株43）の間にあった。この值は，B. stearothermophilus を除く通常の好気性および嫌気性桿菌の 芽胞の D值と著しくかけ離れたものではないといえる [3，4]。実験動物の病原体である Tyzzer 菌の芽胞の熱 抵抗性は, 試験方法の違いがあって直接的な比較は難し いが，通常の芽胞よりも弱い。したがって，医学や獣医
学領域で通常行われている加熱殺菌処理で, 実験動物の 衛生管理に支障はないとは思われる。なお，熱抵抗性と 菌株の由来の間に関連性は認められない。

オゾン暴露実験によると，湿度を90\%に設定しないと 芽胞に対する殺菌効果は実際上認められないこと，そし

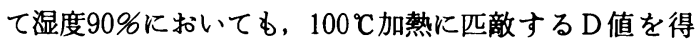
るためには200ppm のオン゙ン暴露が必要なことは明らか である。高い湿度がオゾンの殺菌効果を高める理由につ いては明確でないが，おそらく，殺菌機序の本質である 発生期酸素の形成に水の存在が必須なためである。 た，加熱処理によるD値とオゾン処理によるD値の間に 強い関連は認められなかった。これは，2つの操作にお ける殺菌の機序が異なっているためであろら。

本研究とは別に, 浦野らは芽胞を形成しない通常の細 菌の 8 菌株を用いてオゾン抵抗性について検討し（第36 回日本実験動物学会総会), 実験動物の病原 細菌の多く は100ppm 60分あるいは200ppm 30分の処固によって殺 菌可能と結論されている。伊藤らによれば,一般細菌に 比べて Tyzzer 菌芽胞のオゾン抵抗性は大きいが, 通常 の Bacillus 芽胞よりはオゾン感受性で, 濃度100ppm, 湿度 $90 \%, 1$ 時間の暴露で明らかに活性の低下が認めら れ， 2 時間の暴露で 1 万分の 1 亿低下すると推察された (第36回日本実験動物学会)。

また佐藤らの検討によれば， 4 種類の実験動物由来ウ イルス（センダイウイルス，マウス脳脊噵炎ウイルス， マウス肝炎ウイルス, レオ3 型ウイルス) に対して, (1) 乾燥状態のウイルス材料のオゾン不活化には $80 \%$ 以上の 湿度を必要とし，(2)液体に浮遊させたウイルス材料で は, 供試 4 種類のウイルス中で物理学的処理および化学 的処理にもっとも抵抗性が高いと考えられるレオ 3 型ウ イルスでも, オゾン濃度 $300 \mathrm{ppm}, 4$ 時間の暴露で 10,000 PFU 以上のウイルス不活化効果があるが，(3)ウイルス 浮遊液の性質によっては不活化効果は阻害されるといら (第36回日本実験動物学会)。

これまで, 実験動物施設内部の消毒には，国内外を通 じて一般的にはホルムアルデヒドガスを用いた燻蒸殺菌 （不活化）が行われているが，ホルムアルデヒドの効果 には疑問が残っており，また，ヒトや動物に対して有毒 であるばかりでなく, 強い腐食性, 刺激性のために作 業上にも問題がある $[4]$ 。通常のホルマリン消毒では, $1 \mathrm{~m}^{3}$ あたり約 $6,000 \mathrm{ppm}$ のホルムアルデヒドガスを発 生させているので, 浱度比でみればオン゙ンはきわめて有 効であり, オゾン煄蒸殺菌操作に打ける腐食性, 刺激性 は相対的に著しく低く, 実験動物施設の衛生管理手段と してきわめて有利であると思われる。今後, より幅広い 
検討が望まれる。

\section{要和}

実験動物由来の Bacillus 菌78株の芽胞について熱抵 抗性を検索した。その結果, 41 株の芽胞は70 320 分, 27 株が100 C160分以上抵抗したが, $110^{\circ}$ オオートクレー ブ20分処理にはわずか 1 株が抵抗し， $120^{\circ} \mathrm{C} 5$ 分では 1 株す抵抗できなかった。これら78株中の 9 株の 100 C処 置におけるD值（生菌数を10分の 1 に減少させるに必要 な時間）は5.03〜30.06分の間にあった。続いて，この 9 株についてオゾンガス抵抗性を検索したところ, 湿度 によって殺菌効果が著しく異なり, 湿度60\%, オゾン浱 度 $200 \mathrm{ppm}$ の条件でのD值は200分を越え，とくに 4 株は 1,000分を越し， 6 時間処理においても完全な殺菌は困 難であった。しかし湿度90\%の場合は，200ppm のオデ ンに 6 時間暴露させれば実験動物施設における日常的な 殺菌は可能と思われた。

本研究の 1 部は，文部省科学研究費補助金(総合研究 A)「実 㧱動物施設における娍菌消毒作業マニュアルの作成」(課題番
号：6030408）によって行われた。また，オソンガス暴蕗実験 は，新兴冷熱株式会社の協力の下に，同社製オソン煌蒸装置 ELIOS-ARを用いて行った。関係者各位に深く感斟する。

\section{文 嗝}

[1] Ganaway, J. R. (1980). Effect of heat and selected chemical disinfectants upon infectivity of spores of Bacillus piliformis (Tyzzer's disease). Lab. Anim. Sci, 30, 192-196.

[2] Itoh, T., Ebukuro, M., and Kagiyama, N. (1987). Inactivation of Bacillus piliformis spores by heat and certain chemical disinfectants. Exp. Anim, 36, 239-244.

［3］米虫節夫(1974). 熱隇菌法の基碟. 減菌・消毒法第 1 集. 綿貫 吉・実側佐太郎・栟原欣作編. 文光堂. 東 京.

［4］前島一松本佰弥・高垣善男・加藤英一(1980). 実験 動物衛生管理のための消毒と減菌・ソフトサイエンス 社. 東京.

［5］前島一淑・浦野 徹・佐藤 浩・八神健一(編) (1988). 実倹動物施設における減菌・消毒作業マニュアル.ソフ トサイェンス社. 東京.

[6] Sneath, P. H. A. (1986). Endospore-forming Gram positive rods and cocci. In Bergey's Manual of Systematic Bacteriology Vol.2. Williams \& Wilkins. Baltimore, London, Los Angeles, Sydney. 